\section{UNIVERSITY \\ of DEBRECEN}

FACULTY OF

HeALTH

NYÍREGYHÁZA

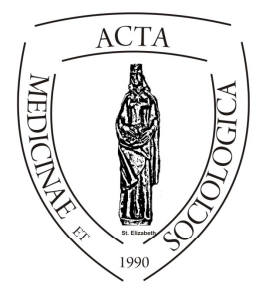

ACTA

MedSOC

VOLUME 8.

2017

\title{
A kezelési szerződés koncepciója a Közös Referenciakeret tervezetében és a BGB- ben, kitekintéssel az Eütv. szabályaira: összehasonlító elemzés
}

\author{
Kiss János Márk
}

Debreceni Egyetem Marton Géza Állam- és Jogtudományi Doktori Iskola

\begin{abstract}
The medical treatment contractin the Draft Common Frame of Reference and the German Civil Codein the view of the Hungarian regulation.

According to the major academical standpoint, the legaltie between the doctor (health care provider) and the patient is a contractual relationship, in which both parties are autonomous, as they also enjoy equal rights. The most legal systems' medicalmal practice law have the same point of view. This is why several Eurpoean countries (e.g. the Netherlands, the CzechRepublic, Germany etc.) regulate the treatment contract as a nominate contract. However other legal sytems do not regard the doctor-patient relationship as contracualtie.

Altough the Hungarian Civil Code does not regulate the treatment contract as a sui generis contract, according to the law practice, the health care provider and the patients are in a horizontal, civil law relation. So it is a question to answer whether there is any practical reason to make treatment contract as a nominate contract in the Civil Code.

The DCFR also names the treatment contract among its model rules. It spurpose is to provide a scheme for EU countries' legislation in order to create a more coherent European contract law. Since the DCFR is representing the EU standards, it might be use das a guideline in the elaboration of the treatment contract's concept.
\end{abstract}


The German Civil Code (BGB) is one of those regulations, which are nominating the doctor-patient relationship as a sui generis contract. Altough they are not related, the BGB's concept is similar to the model ruleset in the DCFR, and since it is an effective regulation, it might be able to reveal if the EU model is applicable in practice or not.

The purpose of this study is - by the comparison of the DCFR's and the BGB's concept - to provide a review of the necessarity and viability of the setting of a sui generis medical treatment contract in the Hungarian Civil Code.

Keywords: medical treatment contract, DCFR, BGB, Eütv, doctor-patient relationship

DOI: $10.19055 /$ ams.2017.8/24/5

Absztrakt. Kulcsszavak: kezelési szerződés, BGB, DCFR, Eütv., orvos-beteg jogviszony Az Európa-szerte egységes szakirodalmi álláspont szerint az egészségügyi szolgáltatás nyújtására irányuló jogviszony magánjogi, szerződéses kötelék, amelyben a felek autonómok, egyenjogúak és mellérendeltek. Az egészségügyi szolgáltatás nyújtásával összefüggésben a betegnek okozott károkkal kapcsolatos perekben kialakult hazai bírói gyakorlat szintén ezt a vonalat képviseli. Ennek ellenére sem a Ptk., sem az ágazati jogszabályok nem rögzítik önálló szerződéstípusként a „kezelési szerződést”.

A magán-egészségügyi szolgáltatások esetében magától értetődően szerződéses megállapodás hozza létre az ellátási kötelezettséget, ezzel szemben a társadalombiztosítási ellátásként nyújtott kezelés esetén erre nincsen szükség, itt a vonatkozó jogszabályok keletkeztetnek jogosultságot az ellátásra. Miként azonban a kezelési szerződés több európai szabályozásban is önálló szerződéstípust képez, ennek lehetősége hazánkban is felmerült. Kérdés tehát, hogy a fentebb leírtak ellenére járhat-e számottevő előnyökkel a kezelési szerződés sui generis szerződéstípusként történő szabályozása. A tanulmány a fenti kérdésre keresi a választ a két olyan koncepció összevetésével, amely szerződéses kötelékként rendezi a felek jogállását.

A kezelési szerződés a Közös Referenciakeret tervezetében (DCFR) rögzített modellszabály vizsgálata azért lehet tanulságos a fenti kérdés körüljárása szempontjából, mert az uniós standardokat megtestesítő ajánlásként megfelelő támpontot nyújthat a kezelési szerződés konstrukciójának kidolgozásához. A német polgári törvénykönyv (BGB) koncepciója azért került a vizsgálat spektrumába, mert számos közös vonást mutat a DCFR modellszabályával, így lehetővé teszi, hogy képet alkossunk az egységes európai uniós koncepcióra vonatkozó elképzelés gyakorlati megvalósíthatóságáról.

\section{Bevezető gondolatok}

Az európai jogrendszerek nagy része magánjogi, szerződéses kötelékként tekint az egészségügyi szolgáltatás nyújtására irányuló jogviszonyra, amelyben a felek autonómok, egyenjogúak és mellérendeltek. ${ }^{1}$ Ennek ellenére a legtöbb állam

\footnotetext{
${ }^{1}$ ld. Günther Brenner: Arzt und Recht, Stuttgart-New York, Gustav Fischer Verlag, 1983, 150-151.; Jobbágyi Gábor: Orvosi jog, Budapest, Szent István Társulat, 2010. 37.
} 
szabályozása nem rögzítisui generis szerződéstípusként a kezelési szerződést, a jogviszony szerződéses jellege pedig kizárólag az orvos, illetve az egészségügyi szolgáltató magánjogi felelőssége kapcsán bír jelentőséggel, más országokban (pl. Finnország, Svédország) pedig fel sem merül, hogy ez a jogviszony kontraktuális kötelék volna. ${ }^{2}$

Hazánkban szintén az egészségügyi szolgáltatás nyújtásával összefüggésben okozott kártérítési, illetve személyiségi jogi perekben kialakult bírói gyakorlat minősíti szerződésnek az egészségügyi szolgáltató és a beteg közötti jogi kapcsolatot. ${ }^{3}$ Ezt támasztja alá, hogy az Eütv. ${ }^{4}$ pontos felsorolást ad a felek jogairól és kötelezettségeiről, illetve, hogy a törvény egészségügyi szolgáltatóról és egészségügyi szolgáltatásról beszél. A törvény tehát magánjogi fogalmak használatával minősíti polgári jogivá az orvos-beteg kapcsolatot. ${ }^{5}$ A Ptk. mégsem rögzíti önálló szerződéstípusként a kezelési szerződést, felek jogállását a nép- és közegészségügyi tárgyú rendelkezéseket is tartalmazó Eütv. szabályozza.

Szintén árnyalja a képet, hogy az új Ptk. ${ }^{6}$ megszüntette a kontraktuális és a deliktuális felelősség szabályai közötti átjárót, létrehozva egy új, az üzleti szféra jogviszonyaira szabott kárfelelősségi tényállást a szerződésszegésre vonatkozó szabályok körében. A Ptk. objektivizált kontraktuális felelősségi konstrukciójának $^{7}$ az egészségügyi szolgáltatással összefüggésben okozott károkért való felelősség megítélése során történő alkalmazása pedig -a szolgáltatás sajátosságait figyelembe véve - ellentétes lett volna a jogalkotói szándékkal. Az Eütv. ezért a Ptk. salátatörvény néven ismert, módosító csomagot tartalmazó 2013. évi CCLII. törvénnyel történt módosítása óta -akként rendelkezik, hogy az egészségügyi szolgáltatásokkal összefüggésben keletkezett kárigényekre a Ptk. szerződésen kívül okozott kárért való felelősségre vonatkozó szabályait kell megfelelően alkalmazni. ${ }^{8}$ A kártérítési felelősség szempontjából tehát már nem bír jelentőséggel, az egészségügyi szolgáltatás nyújtására irányuló jogviszony szerződésként történő minősítése.

A magán-egészségügyi szolgáltatások esetében a kezelés nyújtására irányuló megállapodás teremti meg az egészségügyi szolgáltató ellátási kötelezettséget,

\footnotetext{
${ }^{2}$ MauritsBarendrecht, Chris Jansen, Marco Loos, Andrea Pinna, RuiCascao, Stephanie van Gulijk: Principles of European Private Law, Service contracts, München, Sellier European Law Publishers, 2007., 796.

${ }^{3}$ A Legfelsőbb Bíróság Civilisztikai Kollégiumának emlékeztetője a civilisztikai kollégiumvezetők 2008. január 23-25. napján megtartott országos tanácskozásán megvitatott kérdésekröl, http://ibolyatibor.atw.hu/civkoll.pdf (letöltés időpontja: 2014. október 9.)

${ }^{4}$ az egészségügyről szóló 1997. évi CLIV. törvény (Eütv.)

${ }^{5}$ Jobbágyi Gábor (2010.): i.m. 37. o.

${ }^{6}$ a Polgári Törvénykönyvröl szóló 2013. évi V. törvény (Ptk.)

${ }^{7}$ Ptk. 6:142. §

${ }^{8}$ Eütv. 244.§ (2) bekezdés
} 
ezzel szemben a társadalombiztosítási ellátásként nyújtott kezelés esetén erre nincsen szükség, itt a vonatkozó jogszabályok keletkeztetnek jogosultságot az ellátásra. Miként azonban a kezelési szerződés több európai szabályozásban is önálló szerződéstípust képez, ennek lehetősége hazánkban is felmerült.Kérdés tehát, hogy a fentebb leírtak ellenére járhat-e számottevő előnyökkel a kezelési szerződés sui generis szerződéstípusként történő szabályozása. Jelen tanulmány a fenti kérdésre keresi a választ két olyan koncepció összevetésével, amely szerződéses kötelékként rendezi a felek jogállását.

A kezelési szerződés a Közös Referenciakeret tervezetében (DCFR) ${ }^{9}$ rögzített modellszabály vizsgálata azért lehet tanulságos a fenti kérdés körüljárása szempontjából, mert az uniós standardokat megtestesítő ajánlásként megfelelő támpontot nyújthat a kezelési szerződés konstrukciójának kidolgozásához. A német $\mathrm{BGB}^{10}$ koncepciója azért került a vizsgálat spektrumába, mert számos közös vonást mutat a DCFR modellszabályával, így lehetővé teszi, hogy képet alkossunk az egységes európai uniós koncepcióra vonatkozó elképzelés gyakorlati megvalósíthatóságáról.

\section{A szabályozás célja}

Az egészségügyi ellátás sajátos tárgyára, jelesül az emberi egészségre, testi épségre, illetve életre, mint az emberi személyiség leglényegesebb alkotóelemeire tekintettel, a betegnek a lehető legszélesebb körü kontrollal kell bírnia az őt érintő vizsgálatok, beavatkozások, valamint kezelések felett. Ez pedig olyan fokú autonómiát követel meg, amely a közjogijogviszonyoktól teljesen idegen.Természetesnek tünik tehát, hogy az egészségügyi szolgáltatás nyújtása magánjogi keretek között történik, ami pedig a felek mellérendeltségét is feltételezi.

\section{A kezelési szerződés DCFR-belirögzítésének okai}

Az Európai Közösségek célja, bár kezdettől fogva a töke, a személyek, az áruk, valamint a szolgáltatások szabad áramlásának lehetővé tétele volt, az ezzel kapcsolatos intézkedések nem terjedtek ki a tagállami magánjogi szabályozások harmonizációjára. Az 1990-es évekre viszont megjelent a tagállamközi kereskedelmi tevékenységet korlátozó tagállami rendelkezések leépítésére, illetve a

\footnotetext{
${ }^{9}$ Principles, Definitions and ModelRules of European Private Law, DraftCommonFrame of Reference

${ }^{10}$ BürgerlichesGesetzbuchin der Fassung der Bekanntmachungvom 2. Januar 2002 (BGBl. I S. 42, 2909; 2003 I S. 738)
} 
szerződési jogi szabályozások közelítésére vonatkozó igény. ${ }^{11} \mathrm{Az}$ Európai Civil Kódex Tanulmányi Csoportja, ${ }^{12}$ illetve a Létező Európai Közösségi Magánjog Kutatócsoportja ${ }^{13}$ 2005-ben kapott megbízást a Bizottságtól az európai magánjog közös elveinek, fogalmainak és modellszabályainak megfogalmazására, a Bizottság Egységesebb Európai Szerződési Jog Létrehozására Irányuló Akcióter$\mathrm{ve}^{14}$ keretében. ${ }^{15}$ Ennek eredményeképp született meg a DCFR, amely a Bizottság célkitüzésének megfelelően az egyes szerződéstípusokra vonatkozó modellszabályokat is tartalmaz.

A tervezet célja tehát a tagállami szerződési jogi szabályozások közelítése, amely során komoly jelentőséggel bírnak - az Unió által képviselt értékrendet is megtestesítő - alapelvek. A DCFR a szerződési alapelvek körében rögzíti a gyengébb fél védelmének elvét, ${ }^{16}$ amely az Unió fogyasztóvédelemi, illetve a munkajogi tárgyú szabályozásaiban is megjelenik.

Kétségtelen, hogy az egészségügyi szolgáltatás igénybevételére irányuló jogviszonyban a beteg pozíciója gyengébb az egészségügyi szolgáltatóénál. A beteg az esetek jelentős részében - egészségi állapotából adódóan - rászorul az ellátásra, a kezelésre így feltétlenül- és gyakran azonnal - szükség van. Ezzel összefüggésben meg kell még említeni a beteg és a kezelést nyújtó egészségügyi dolgozó közötti információs aszimmetriát, amely probléma áthidalása szintén elengedhetetlen a beteg tényleges autonómiájának, illetve mellérendelt pozíciójának biztosításához.

Megjegyzendő, hogy az egészségügyi szolgáltatások nem tartoznak a szolgáltatási irányelv hatálya alá, ${ }^{17}$ így az abban rögzített, a szolgáltatást igénybe vevő fél védelmét szolgáló garanciák nem vonatkoznak a betegekre. A pácienst az egészségügyi szolgáltatással összefüggésben megillető jogok szabályozása így a tagállamok hatáskörében marad. A DCFR ezért a kezelési szolgáltatásokra vonatkozó szabályok körében speciális védelmet nyújt a betegnek. ${ }^{18} \mathrm{~A}$ kezelési

\footnotetext{
${ }^{11}$ Török Éva: Az európai szerződési jog fejlődésének tendenciái, Debreceni Jogi Mühely, VIII. évf. 4. sz.

http://www.debrecenijogimuhely.hu/archivum/4_2011/az_europai_szerzodesi_jog_fejlo desenek_tendenciai (letöltés időpontja: 2016. november 28.)

${ }^{12}$ Study Group ona European Civil Code

${ }^{13}$ Research Group onExisting EC Private Law

${ }^{14}$ COM 2003/C 63/01 - Action Planon a More Coherent European Contract Law

${ }^{15}$ DCFR General 1.

${ }^{16}$ a DCFR eredeti terminológiája szerint protectthevulnerable: a sebezhetők védelme

${ }^{17}$ Az Európai Parlament és a Tanács 2006/123/EK irányelve a belső piaci szolgáltatásokról 2. cikk (2) bekezdés f) pont

${ }^{18}$ Principles, Definitions and ModelRules of European Private Law, DraftCommonFrame of Reference (DCFR) 70. http://ec.europa.eu/justice/contract/files/european-privatelaw_en.pdf (letöltés időpontja: 2017. január 8.)
} 
szerződés alkalmazásának a társadalombiztosítási ellátásként nyújtott egészségügyi szolgáltatásokra való kiterjesztése pedig - a tervezet megfogalmazóinak elképzelése szerint - az egészségügyi szolgáltatások nyújtásának olyan egységes jogi szabályozásának kialakítását szolgálná, amely alkalmas a világosság, a jogbiztonság, valamint a beteg, mint fogyasztó érdekeinek védelmére. ${ }^{19}$

A DCFR koncepciója mögött tehát a beteg pozíciójának erősítése, jogainak védelme húzódik. Fontos viszont kiemelni, hogy a tervezet fogyasztóként tekint a betegre, így a szerződés sajátos tárgyára tekintettel meghatározott speciális jogok és kötelezettségek is a „gyengébb fél” védelmét célozzák. Bár a fogyasztó pozíciójának sajátosságai a beteg státuszát egyaránt jellemzik, az emberi élet, testi épség, illetve egészség érintettsége miatt a beteget az egészségügyi szolgáltatással összefüggésben megillető jogok sokkal inkább az alapvető emberi jogokhoz, semmint a fogyasztói jogokhoz köthetők. Sőt, ezek a jogosultságok, önálló jogi kategóriaként, betegjogokként jelennek meg nem csak az Eütv-ben, hanem a vonatkozó nemzetközi egyezményekben, más államok egészségügyi jogi szabályozásában és a külföldi szakirodalomban is.

Bár a betegjogok az egészségügyi szolgáltatás igénybevételével összefüggésben, vagyis a kezelési szerződés keretei között illetik meg a beteget, nem eshetnek a fogyasztói szerződésekben szereplő szolgáltató kötelezettségeivel azonos megítélés alá. A betegjogok nem az egészségügyi szolgáltatást igénybe vevö fogyasztó vagyoni érdekeit védik, hanem a beteg, mint ember személyiségét. Ennek megfelelően a megsértésükhöz füződő felelősség is eltérően alakul: a fogyasztói szerződésből eredő szavatossági igények (kijavítás, kicserélés) érvényesítésével kapcsolatos szabályok az egészségügyi szolgáltatásokkal összefüggésben csak szük körben vagy egyáltalán nem alkalmazhatók. A betegjogok megsértése kapcsán csakis a nem vagyoni - illetve a személyiségi jogok megsértésével összefüggésben felmerült vagyoni - kártérítés jöhet szóba.

\section{A kezelési szerződés megjelenése a BGB-ben}

A német jogirodalom, illetve bírói gyakorlat évtizedek óta határozottan szerződéses kötelékként tekint az orvos-beteg jogviszonyra. ${ }^{20}$ Ezt az álláspontot a Szövetségi Alkotmánybíróság a következőképpen erősítette meg: „Az orvos és a beteg közötti jogviszony Eberhard Schmidt szerint sokkal több, mint egy szerzödéses kapcsolat. Az orvosetika nem különül el a jogi szabályozástól,

\footnotetext{
${ }^{19}$ DCFR 1954. http://ec.europa.eu/justice/contract/files/european-private-law_en.pdf (letöltés időpontja: 2017. január 8.)

${ }^{20}$ Jobbágyi Gábor: Orvosi kezelési szerződés - új szerződésfajta a BGB-ben, In: Tanulmányok a 65 éves Lenkovics Barnabás tiszteletére, Budapest - Győr, Eötvös József Könyv-és Lapkiadó Bt. - Széchenyi István Egyetem Deák Ferenc Állam- és Jogtudományi Kara, 2015.,193.
} 
folyamatosan jelen van az orvos betegekkel való kapcsolataiban. Az etikai normák által támasztott követelmények jogi kötelezettségekként is megjelennek. Az orvosi tevékenység esetében az etikai szabályok sokkal jobban összefolynak a jogi normákkal, mint bármely más területen. Ez napjainkban is így van, a beteg önrendelkezési jogának figyelembevétele lényeges eleme az orvosi kötelezettségek körének.

A Szövetségi Alkotmánybíróság a fentieket az orvosi felelősség kapcsán, azon belül is a tájékozott beleegyezés követelményével összefüggésben mondta ki. Mind a beteg autonómiája, mind pedig az abból fakadó tájékozott beleegyezés követelménye az emberi élet, testi épség és egészség érintettségével állnak összefüggésben. Nem elég tehát deklarálni az orvos-beteg kapcsolat szerződéses jellegét, meg kell határozni a beteg autonómiáját biztosítani képes, a pácienst az egészségügyi szolgáltatás igénybevétele során megillető jogokat.

A Németországban - egészen a BGB 2013-ban történt módosításáig - a beteget az egészségügyi ellátással összefüggésben megillető jogok nem voltak katalogizálva, így ezeket a bírói gyakorlat munkálta ki az egészségügyi szolgáltató kezelési hibákért való felelősségével kapcsolatos perekben. Bár a Szövetségi Orvosi Kamara (Bundesärztekammer) szakmai szabályzata ${ }^{22}$ ezt megelőzően is tartalmazott betegjogi tárgyú rendelkezéseket ígytöbbek között az emberi méltóság tiszteletben tartását, ${ }^{23}$ a tájékoztatási kötelezettséget, ${ }^{24}$ illetve a dokumentációs kötelezettséget, ${ }^{25}$ átfogó betegjogi szabályozás nem létezett.

A kezeléssel érintettalapvető jogok, így különösen az élethez való jog, az emberi méltósághoz való jog, valamint az önrendelkezés jogának védelme azonban megköveteli a fenti jogok az orvos-beteg kapcsolat sajátosságainak figyelembe vételével történő specializálását. A jogbizonytalanság továbbá az egészségügyi szolgáltató helyzetét is megnehezíti, hiszen a betegjogok tételes felsorolása, illetve azok tartalmának pontos meghatározása hiányában nincsenek tisztában az esetleges felelősségre vonásukat megalapozó kötelezettségeikkel.

A jogbiztonsággal és az alapvető jogok védelmével kapcsolatos megfontolások mellett kiemelendő, hogy az orvosi felelősség - a gazdag bírói esetjognak köszönhetően - kiterjedt, komoly gyakorlati relevanciával bíró területté fejlö-

\footnotetext{
${ }^{21}$ BVerfG, 25.07.1979 - BvR 878/74 (108)

22 (Muster-)Berufsordnungfür die inDeutschlandtätigenÄrztinnen und Ärzte - MBO-Ä 1997

${ }^{23} \mathrm{MBO}-\ddot{\mathrm{A}} \S 7(1)$

${ }^{24} \mathrm{MBO}-\ddot{\mathrm{A}} \S 8$

${ }^{25} \mathrm{MBO}-\ddot{\mathrm{A}} \S 11$
} 
dött, így e szempontból is indokoltnak tekinthető a betegjogok, illetve az egészségügyi szolgáltató és a beteg közötti kötelék törvényi szabályozása. ${ }^{26}$

A betegjogok szabályozására vonatkozó igény azonban nem jelenti automatikusan a kezelési szerződés sui generis szerződéstípusként történő rögzítésének szükségességét. Az egészségügyi szolgáltatások nyújtásának szabályozása körében - legalábbis Európában - figyelembe kell venni, hogy az esetek jelentős részében a beteg a társadalombiztosítás rendszerében nyújtott ellátásként veszi igénybe egészségügyi szolgáltatást, az ilyen ellátásokra pedig nem lehet tisztán szerződéses megállapodás alapján nyújtott - szolgáltatásként tekinteni.A BGB módosítását is tartalmazó betegjogi törvény $(\mathrm{PRG})^{27}$ előkészítése során - az egészségbiztosítási vonatkozások kapcsán - felmerült tehát a közjogi szabályozás lehetősége is.

Az úgynevezett ellátási koncepció (Versorgungskonzeption) szerint az orvos az egészségügyi szolgáltatást a betegnek, mint biztosítottnak egészségbiztosítási ellátásként nyújtja, így az ellenszolgáltatást sem a beteg, hanem az egészségbiztosító teljesíti, így ez a jogviszony nem tekinthető magánjoginak. ${ }^{28}$

A Szövetségi Legfelsőbb Bíróság (Bundesgerichtshof) gyakorlata, ${ }^{29}$ illetve a szakirodalmi álláspont ${ }^{30}$ szerint a biztosított is az egészségügyi szolgáltatóval kötött szerződés alapján veszi igénybe az ellátást. Ezt támasztja alá betegautonómiájának elismerése, az orvos gyógymódválasztási szabadsága, illetve az orvos és a beteg közötti bizalmi kapcsolat. Ezek a magánjogi jegyek az egészségbiztosítási ellátásként nyújtott kezelés esetében is jellemzik az orvos-beteg köteléket, a jogalkotó ezért a magánjog szabályozás mellett döntött. ${ }^{31}$

Németországban tehát a kezelési szerződés BGB-beli rögzítését megelőzően a betegjogok az egészségügyi szolgáltatások igénybevételével összefüggésben keletkezett károkért való felelősséggel összefüggö bírói gyakorlat által kimunkált formában léteztek. Azonban, részben a fentebb említett alkotmányjogi megfontolások, de főként az egészségügyi szolgáltató felelősségre vonásának kereteit tisztázó szabályozás iránti igény miatt elengedhetetlenné vált egy átfogó betegjogi szabályozás megalkotása. Az orvos és a beteg közötti kapcsolat határozottan magánjogi vonásaira tekintettel a jogalkotó az egészségügyi szolgáltatás-

\footnotetext{
${ }^{26}$ Dominik Franzki: Der Behandlungsvertrag, EinneuerVertragstypusimBürgerichenGesetzbuch, Göttingen, Universitätsverlag Göttingen, 2014., 42.

${ }^{27}$ GesetzzurVerbesserung der Rechte von Patientinnen undPatientenvom 20. Februar 2013. (PRG)

${ }^{28}$ Dominik Franzki: i.m. 50.

${ }^{29}$ BGH, 17.12.1985 - VI ZR 178/84 stb.

${ }^{30}$ Jobbágyi Gábor: i.m. 193.

${ }^{31}$ Dominik Franzki: i.m. 51.
} 
sal összefüggésben a beteget megillető jogokat szerződéses kötelezettségként határozta meg.

A fentiek alapján kitünik, hogy a DCFR és a BGB koncepciójának megalkotása mögött teljesen eltérő megfontolások húzódnak. A beteg érdekeinek védelme mindkét esetben elsődleges szempont volt. Azonban, míg a DCFR a beteget fogyasztóként kezeli, és gyengébb félként védi az egészségügyi szolgáltatóval, mint a gazdasági értelemben vett szolgáltatóval szemben, addig a BGB az emberi személyiség védelmét helyezi előtérbe. Kiemelendő továbbá, hogy Németországban már a betegjogok - meglehetősen kései - szabályozását megelőzően jelentős bírói gyakorlat alakult ki az egészségügyi szolgáltatásokkal összefüggésben elszenvedett károk miatti igényérvényesítések kapcsán. Ez pedig már önmagában indokolttá teszi a gyakorlat vívmányainak a jogi szabályozásba történő átültetését és ezzel jogviszony kereteinek rendezését.

Az egészségügyi szolgáltatásokkal összefüggésben elszenvedett károk miatti perek gyakorisága kapcsán megjegyzendő, hogy az, hogy a beteg úgy dönt, hogy magánjogi úton érvényesít igényt az egészségügyi szolgáltatóval szemben, fogyasztói szemléletre utal, ${ }^{32}$ ez vitathatatlan. A személyes gyakorlati tapasztalataim azonban azt mutatják, hogy egy, a kezeléssel összefüggésben kárt elszenvedett beteg attitüdje, aki igényei érvényesítése érdekében tanácsért, illetve jogi képviseletért folyamodik, merőben eltér a fogyasztói igényt keresztülvinni kívánó ügyfélétől. Az igényérvényesítést ilyenkor a személyiségi jogi sérelmek motiválják, a beteget, mint „fogyasztót” megillető jogok megsértése kizárólag a követelés jogalapja körében bírnak jelentőséggel. Ezzel összefüggésben megjegyzendö, hogy a betegjogok sérelme is képezheti sérelemdíj iránti igény jogalapját, azonban az ilyen tárgyú jogviták középpontjában a testi épség, illetve egészség megsértésére tekintettel követelt kompenzáció áll.

\section{A „kezelési szerződés” a magyar jogban}

Amint az a bevezetőben leírtakból is kitünik, számos jogrendszerben, így hazánkban is az egészségügyi szolgáltatással összefüggésben elszenvedett károkért való felelősséggel összefüggésben merült fel először az egészségügyi szolgáltatás nyújtására irányuló szerződés kérdése.

Az elmúlt két évtizedben számos olyan felsőbírósági döntés született, amely a jogviszony kontraktuális természetének rögzítésén túlmenően megállapításokat tesz a szerződés tartalma tekintetében is. Kiemelendő a Pécsi Ítélőtábla azon álláspontja, mely szerint,, az [...] orvos és a beteg - az egészségügyi szolgáltató

\footnotetext{
${ }^{32}$ Dósa Ágnes: Az orvos kártérítési felelőssége, Budapest, HVG-ORAC, 2010., 9.
} 
és a páciens - kapcsolata alapvetö, lényegi elemeiben polgári jogi szerződéses jogviszony, amelyet az igénybevevö erre irányuló szándéka hoz létre. [...] Az orvosi jogviszony körében a szerzödés célja a beteg egészségi, testi állapotának elönyös változása, amelynek érdekében a beteg nem csupán beleegyezik, de kifejezetten igényli az orvosi beavatkozás folytán megvalósuló "testi sértést», a szerzödés célja és tartalma által meghatározott keretek között. ",33

Minthogy azonban a kezelési szerződést sem a Ptk. sem pedig egyéb jogszabály nem rögzíti önálló szerződéstípusként, felmerül a kérdés, hogy mit értünk a szerződés tartalma alatt. Nyilvánvaló, hogy a szerződés tartalmát jelentős részben az Eütv. szabályai teszik ki. ${ }^{34} \mathrm{Az}$ egészségügyi szolgáltatások nyújtására vonatkozó kógens rendelkezésekként a felek közötti jogviszony jellegére való tekintet nélkül állapítanak meg jogokat, illetve kötelezettségeket mindkét félre nézve. Az ellátásban résztvevő egészségügyi dolgozókat hivatásuknál fogva kötik továbbá az etikai normák és a szakmai szabályok. ${ }^{35}$

Hasonlóan összetett kérdés a szerződés tárgyát képező kezelés, mint szolgáltatás minősítése. Az Eütv. az egészségügyi tevékenység fogalmának meghatározásakor a beteg vizsgálatára és kezelésére, gondozására, ápolására, egészségügyi rehabilitációjára, a fájdalom és a szenvedés csökkentésére, továbbá a fentiek érdekében a beteg vizsgálati anyagainak feldolgozására irányuló egészségügyi tevékenységek összességéről beszél. ${ }^{36}$ Később a törvény az egészségügyi szolgáltatások céljaként az egészség fejlesztéséhez, lehetséges mértékủ helyreállitásához, az egészségromlás mérsékléséhez való hozzájárulást, valamint a megváltozott egészségi állapotú egyének munkába és közösségbe való beilleszkedésének elősegítését jelöli meg. ${ }^{37}$ Rögzíteni kell továbbá, hogy a beteg felgyógyulása nem kizárólag az orvostól függ, számos egyéb tényező is közrejátszik, melyek pontos felmérése és észlelése szinte lehetetlen. ${ }^{38} \mathrm{~A}$ fentiekböl kitünik, hogy az egészségügyi szolgáltatás nyújtása végső soron eredmény elérésére irányul ugyan, e tevékenység fö tárgya viszont - az eredménykötelmekkel ellentétben mégsem az eredményszolgáltatás. A törvény szóhasználata („hozzájárulás, elősegítés") is arra utal, hogy itt az eredmény egy távolabbi célkitüzés. Az orvos

\footnotetext{
${ }^{33}$ Pécsi Ítélőtábla Pf.II.20.115/2009.

${ }^{34}$ Kemenes István: Az orvos kártérítési felelősségének egyes kérdései, Bírósági Döntvények Tára 2008/1. 5. oldal.

${ }^{35}$ Eütv. 77. $§(3)$ bekezdés

${ }^{36}$ Eütv. 3.§ e) pont

${ }^{37}$ Eütv. 75.§ (2) bekezdés

${ }^{38}$ Törő Károly: Az orvosi polgári jogi jogviszony, Budapest, KJK, 1965., 23. o.
} 
tehát nem a beteg meggyógyítását vállalja, hanem csupán az annak érdekében történő gyógykezelést. ${ }^{3}$

Ezzel szemben rögzíteni kell, hogy számos olyan orvosi tevékenységfajta létezik, amely esetében az eredmény elérése az uralkodó. Ilyen például a fogpótlás elkészítése, amely minden jogrendszerben, így a magyarban is eredménykötelem. ${ }^{40}$ A plasztikai beavatkozások esetén a beteg szintén eredményt vár el a beavatkozástól, a bírói gyakorlat ennek ellenére megbízási szerződésnek tekinti a plasztikai mütét elvégzésére irányuló megállapodást. ${ }^{41}$

E körben meg kell említeni, hogy a gondossági mérce eltér a Ptk-ban rögzített általában elvárhatóság követelményétől. ${ }^{42}$ A már említett Eütv. 77. § (3) bekezdése ugyanis rögzíti, hogy minden beteget - az ellátás igénybevételének jogcímére tekintet nélkül - az ellátásában résztvevőktől elvárható gondossággal, valamint a szakmai és etikai szabályok, illetve irányelvek betartásával kell ellátni. A Legfelsőbb Bíróság vonatkozó gyakorlata szerint a kártérítési felelősség alóli kimentés körében is ez a mérce tekintendő irányadónak. ${ }^{43}$ Mivel pedig az ellátásban való részvétel ténye feltételezi az ahhoz szükséges képzettség meglétét, a kezelést nyújtó féltől elvárt gondosság az általános követelményhez képest fokozottnak tekinthetö.

A bírói gyakorlat és az Eütv. tehát egy megbízási típusú szerződést körvonalaz, amelynek tartalmát az ágazati jogszabályi rendelkezések és az egészségügyi szférában dolgozókra vonatkozó, a jogi szabályozás körén kívül eső - etikai és szakmai - szabályok határozzák meg. A jogtudomány hazai képviselőinek jelentôs része ${ }^{44}$ szintén így vélekedik. Jobbágyi Gábor szerint az orvos-beteg jogviszony nem megbízás. Érvei között szerepel a személyes munkavégzési kötelezettség és a megbízó (beteg) széleskörű utasítási jogának hiánya, továbbá az is, hogy a megbízást mindkét fél felmondhatja, az egészségügyi intézmény azonban kevés esetben tagadhatja meg a beteg ellátását. ${ }^{45}$ Fontos továbbá kiemelni Papp Tekla álláspontját, mely szerint a kezelési szerződés az atipikus szerződések köréhez tartozik. ${ }^{46}$

\footnotetext{
${ }^{39}$ Tarr György: Gondolatok az orvosi jogról és az orvosi jogviszonyról, Magyar jog, XCIX. évfolyam I. szám, 26.

${ }^{40}$ Jobbágyi Gábor (2010): i.m. 38., PKKB. 31. P. 89.625/1994.

${ }^{41}$ LB. Pfv.III.22 627/1999.

${ }^{42}$ Ptk. 1:4. $\S(1)$ bekezdés

${ }^{43} \mathrm{EH} 2008.1867$.

${ }^{44}$ példáulVillányi László, Csanádi György, Eörsi Gyula és Lábady Tamás ld. Tarr György: i.m. 22-23.

45 Jobbágyi Gábor (2010.): i.m. 43.

${ }^{46}$ Papp Tekla: Atipikus szerződések, Lectum Kiadó, Szeged, 2009. 18-23.
} 


\section{A kezelési szerződés koncepciója a DCFR-ben és a BGB-ben}

\section{A kezelési szerződés helye a DCFR és a BGB rendszerében}

A DCFR a modellszabályok (ModelRules) körében az ,egyes szerződések és az azokból folyó jogok és kötelezettségek" címet viselő IV. könyv, a szolgáltatási szerződésekről szóló C) részében helyezi el a kezelési szerződést. Ebben a részben megbízási és vállalkozási típusú szerződések egyaránt találhatók, kitünik tehát, hogy a tervezet csupán a jogviszony tárgya alapján differenciál a szerződéstípusok között, így a kezelési szerződés, a DCFR rendszerében való elhelyezkedése alapján nem következtethetünk a szolgáltatás gondossági, illetve eredménykötelem jellegére.

A BGB is hasonló megoldást követ, a kezelési szerződést ugyanis a kötelmi jogi könyv, az egyes szerződésekről szóló fejezetében, a szolgáltatási szerződés és hasonló szerződések címének egyik alcímeként szabályozza. A BGB egyébként háttérszabályaként rendeli alkalmazni a szolgáltatási jogviszony szabályait, ${ }^{47}$ a kezelési szerződés tehát a szolgáltatási szerződés egyik altípusának tekinthető. A kezelési szerződés gondossági kötelmi természete már a BGB rendszerében elfoglalt helye alapján kitünik.

\section{A kezelési szerződés fogalma}

A DCFR nem kezelési szerződés fogalmának rögzítése, hanem a fejezet alkalmazási körének megjelölése útján határozza meg felek pozícióját, illetve a szolgáltatás tárgyát .

E fejezet azon szerzödésekre vonatkozik, amelyekben az egyik fél, a kezelést nyújtó egészségügyi kezelés nyújtását vállalja, egy másik fél, a beteg számára. A fejezet megfelelöen alkalmazandó bármely egyéb olyan szerzödés tekintetében, amely egy személy fizikai, illetve mentális állapotának megváltoztatására irányuló szolgáltatás nyújtására vonatkozik.

Amennyiben nem a beteg a szerzödö fél, úgy egy olyan harmadik félnek tekintendö, akire nézve a szerzödés az egészségügyi szolgáltató jelen fejezetben meghatározott kötelezettségeivel korrelációban jogokat keletkeztet. ${ }^{48}$

A tervezetelsődlegesen kifejezetten az egészségügyi kezelések vonatkozásában rendeli alkalmazni a fejezet rendelkezéseit. Összevetve az egészségügyi szolgáltatás, az Eütv. 3. § e) pontjában rögzített fogalmával, a kezelési szerződés tárgyának DCFR-beli meghatározása pontatlannak tünhet, fontos azonban, hogy

\footnotetext{
${ }^{47} \mathrm{BGB} \S 630 \mathrm{~b}$

${ }^{48}$ DCFR IV. C. $-8: 101$ (1)-(3)
} 
az Eütv. közjogi tárgyú jogszabályként egy sor olyan tevékenységet, illetve ellátást is a szabályozási körébe von, amely tekintetében a III. fejezetben leírtak nem irányadók. Így például a köz-, illetve népegészségügyi vonatkozású egészségügyi szolgáltatásokkal összefüggésben - a törvényben megjelölt kivételektől eltekintve - a betegjogok, az azokkal korreláló, az egészségügyi szolgáltató oldalán felmerülő kötelezettségekkel egyetemben változatlanul irányadók.

Figyelemreméltó viszont, hogy a DCFR a kezelési szerződés alkalmazási körébe von minden olyan szolgáltatást, amely egy személy mentális vagy fizikai állapotának megváltoztatására irányul. ${ }^{49} \mathrm{E}$ rendelkezés látszólag az (1) bekezdésben említett egészségügyi kezelés fogalmát rögzíti. Itt azonban a kezelési szerződés alkalmazási körének az olyan tevékenységekre történő kiterjesztéséről van szó, amelyek nem tekinthetők orvosi ellátásnak. Egyes szolgáltatások (pl. pszichoterápia) esetében magától értetődik a kezelési szerződés alkalmazása, a tervezet megfogalmazói azonban - a szolgáltatások színvonalának növelése, illetve a fogyasztók védelme érdekében - olyan tevékenységek vonatkozásában is lehetővé tennék a kezelési szerződés alkalmazását, mint a fodrászat vagy a kozmetika. ${ }^{50}$

A fejezet alkalmazási körével összefüggésben kiemelendő továbbá, hogy a tervezet rendezi a felek pozícióját a (társadalom)biztosítási szolgáltatásként nyújtott egészségügyi szolgáltatások tekintetében is, a modellszabály ugyanis egy olyan esetkört is említ, amikor nem a beteg a szerződő fél, hanem a jogviszonyból eredő jogok alanyaként, tulajdonképpen a kezelési szerződés kedvezményezettje.

A BGB - a Ptk. által is követett módszerrel - a kezelési szerződés fogalmának megjelölése útján rögzíti a jogviszony kereteit:

A kezelési szerzödés által az orvosi kezelést vállaló fél (Kezelést nyújtó), a vállalt kezelés nyújtására, a másik fél (Páciens) pedig az általa vállalt ellenszolgáltatás teljesitésére köteles, amennyiben ez nem egy harmadik fél kötelezettsége.

A BGB szerinti kezelési szerződés-fogalom egyetlen és - látszólag - jelentős eltérése DCFR (1) bekezdéséhez képest az ellenszolgáltatásra vonatkozó rendelkezés. Az, hogy a tervezet nem tartalmaz ilyet, nem jelenti azt, hogy az Európai Unió az egészségügyi szolgáltatások ingyenességét preferálná. Az egészségügyi szolgáltatás finanszírozása azonban az esetek zömében egy harmadik fél - többnyire az állami egészségbiztosító - bevonásával történik, az ezzel kapcsolatos részletszabályok kidolgozása viszont több, mint amire a DCFR koncepciója, mint - hangsúlyozottan - modellszabály hivatott.

E körben fontos még megemlíteni, hogy a BGB szerint a beteg ellenszolgáltatás teljesítésére vonatkozó kötelezettsége szubszidiárius, csak abban az esetben áll

\footnotetext{
${ }^{49}$ DCFR IV.V. 8:101. (3) bekezdés

${ }^{50}$ DCFR 1953. http://ec.europa.eu/justice/contract/files/european-private-law_en.pdf (letöltés időpontja: 2017. január 8.)
} 
fenn, ha az nem a már említett harmadik fél kötelezettsége. A fentiek alapján tisztán látszik, hogy a BGB elsődleges célja nem a magánszférában nyújtott egészségügyi szolgáltatások szerződéses kereteinek kidolgozása volt, hanem az egészségügyi szolgáltatás nyújtására irányuló jogviszony szabályozása. Egy - kifejezetten a magán egészségügyi szolgáltatások körében irányadó - fogyasztóvédelmi célt szolgáló rendelkezési azonban mégis ki kell emelni: a BGB §630c (3) bekezdés alapján, amennyiben a kezelés az ellátás diját nem a harmadik fél viseli, a kezelést nyújtó fél köteles írásban tájékoztatni a beteget a díj mértékéről.

Figyelembe véve ezzel szemben a DCFR által célzott - a belső piac müködését, azon belül is a szolgáltatásnyújtás szabadságának legteljesebb körü érvényesülését szolgáló - jogharmonizációt, megállapítható, hogy a tervezet - azzal együtt, hogy meghagyja a kezelési szerződés a társadalombiztosítási ellátásként nyújtott egészségügyi szolgáltatások vonatkozásában történő alkalmazásának lehetőségét - a magánszférában, fogyasztók számára nyújtott szolgáltatásokra koncentrál.

\section{A gondossági mérce}

A DCFR a fejezet alkalmazási körét követően az egészségügyi szolgáltató kötelezettségeit taglalja, melyek közül az elvárható szaktudás és gondosság követelménye bír kiemelkedő jelentőséggel. A tervezet ugyanis e körben - kógens éllel - meghatározza az egészségügyi szolgáltatás nyújtása során követendő mércét:

A kezelést nyújtó szaktudására és gondosságára vonatkozó követelmény megköveteli különösen, hogy a kezelést nyújtó olyan gondossággal és szaktudás birtokában nyújtsa szolgáltatását, amilyet egy ésszerü kezelést nyújtó tanúsitana az adott körülmények között. ${ }^{51}$

A DCFR által meghatározott gondossági mérce tehát lényegében megegyezik az Eütv.-benrögzített, az ellátásban résztvevőktől elvárható gondosság követelményével. ${ }^{52} \mathrm{Az}$ ezzel összefüggésben fentebb leírtak megismétlésétől eltekintvén ehelyütt csupán annyit rögzítek, hogy a fenti rendelkezés alapján nyilvánvaló, hogy az egészségügyi szolgáltató nem a beteg meggyógyítására, mint eredmény produkálására, hanem az annak érdekében - a tőle általában elvárható gondossággal - történő ellátásra vállal kötelezettséget. A kezelési szerződés tehát a DCFR koncepciója szerint is gondossági kötelmet keletkeztet.

A DCFR a fentiekhez hasonló követelményt támaszt a kezelés során alkalmazott eszközök, gyógyszerek, anyagok, felszerelések és a kezelés nyújtására szolgáló helyiség tekintetében. Ezeknek ugyanis meg kell felelniük a professzio-

${ }^{51}$ DCFR IV. C.-8:104 (1)

${ }^{52}$ Eütv. 77. $§(3)$ bekezdés 
nális gyakorlatban elfogadott minőségi követelményeknek, valamint a vonatkozó jogszabályi rendelkezéseknek. ${ }^{53}$

A BGB a kezelési szerződés teljesítése vonatkozásában nem határoz meg sajátos gondossági követelményt, így a BGB §630b-ben foglalt rendelkezés alapján alkalmazandó szolgáltatási szerződésre vonatkozó szabályok körében alkalmazott adott helyzetben elvárható teljesítés követelménye irányadó. ${ }^{54}$ A BGB §630a (2) bekezdése alapján azonban - eltérő megállapodás hiányában - a kezelés időpontjában elismert szakmai standardoknak megfelelően kell nyújtani a kezelést.

A BGB tehát a gondosság körében nem differenciál, ehelyett a fenti keretszabállyalbeemeli a szakmai szabályokat a szerződésből eredő kötelezettségek körébe. A hazai szabályozás is hasonlóan alakul, az Eütv. 77. § (3) bekezdése ugyanis az ellátásban résztvevőktől elvárható gondosság követelményén kívül a szakmai és etikai szabályok, illetve irányelvek betartását is előírja.

Kérdéseket vethet fel a mindenkori szakmai, etikai szabályok, illetve irányelvek betartására vonatkozó kötelezettség diszpozitivitása. Ezek biztosítják ugyanis az ellátás megfelelő színvonalát, így elhagyásuk meglehetősen hátrányos volna a beteg szempontjából. A páciens önrendelkezési jogát figyelembe véve mégis értelmet nyerhet az eltérés lehetősége. A beavatkozás folyamán ugyanis felmerülhetnek olyan helyzetek, amikor nincs lehetőség a beteg tájékozott beleegyezésének megszerzésére. A beteg halálával vagy maradandó károsodásával fenyegető közvetlenül helyzetekben az ilyen eredmény elkerülése a kezelést nyújtó orvos - a beteg beleegyezése hiányában is - köteles megtenni - a szakmai protokoll szerinti - szükséges intézkedéseket. ${ }^{55}$ Előfordulhat azonban, hogy a beteg - pl. vallási meggyőződése okán - a szakmai szabályok szerint alkalmazandó beavatkozásba nem egyezne bele. ${ }^{56} \mathrm{~A}$ felek - a szakmában megszokott beavatkozás helyett alternatív kezelés alkalmazására vonatkozó - megállapodása ilyen esetben feloldhatja az emberi élet, testi épség és egészség védelméhez füződő társadalmi érdek és a beteg önrendelkezési joga, illetve - a lábjegyzetben

\footnotetext{
${ }^{53}$ DCFR IV. C. $-8: 103$ (1)

${ }^{54}$ BGB $\S 612$ abs. (1)

${ }^{55}$ vö.Eütv. 125. $\S$, illetve 18. $\S$ (1) bekezdés a) pont.

${ }^{56}$ A Semmelweis Egyetem Egészségtudományi Kara által 2016-ban, Az egészségügyi ellátás aktuális jogi és etikai kérdései címmel szervezett V. Betegjogi szakmai nap egyik workshopja a Jehova Tanúi Egyház tagjainak orvosi ellátásával kapcsolatos kihívásokról szólt. A Bibliában található kijelentések értelmezése alapján számukra ugyanis az allogénvértranszfúzió (azaz a teljes vér, vörösvértestek, fehérvérsejtek, vérlemezkék, és a plazma használata) illetve a preoperatívautológ vérgyüjtés elfogadhatatlan. http://semmelweis.hu/betegjogi-konferencia/files/2012/02/Program-2016-honlapra.pdf (letöltés időpontja: 2016. október 26.)
} 
jelölt esetben felmerült - vallásszabadsághoz füződő alapvető joga közötti döntés problémáját.

\section{Betegjogi tárgyú és egyéb rendelkezések a BGB-ben és a DCFR-ben}

A DCFR és a BGB egyaránt rögzíti az egészségügyi szolgáltató tájékoztatási kötelezettségét, a tájékozott beleegyezés követelményét, az egészségügyi dokumentáció vezetésére vonatkozó kötelezettséget, valamint - utóbbival összefüggésben - a dokumentáció megismerésének jogát. E rendelkezések részletekbe menő tárgyalásától jelen keretek között eltekintek, az egyes betegjogok, illetve - a DCFR és a BGB esetén - az egészségügyi szolgáltató kötelezettségeinek tartalma a kezelési szerződés hazai szabályozása szempontjából nem bír relevanciával.

Fontos viszont, hogy míg az Eütv. a betegjogokat, illetve az egészségügyi szolgáltató és az ellátásban résztvevő egészségügyi dolgozók a beteget megillető jogosultságokkal korrelációban lévő kötelezettségeit közjogi éllel egy, a teljes egészségügyi ágazatra kiterjedő hatállyal szabályozza, addig a BGB és a DCFR szerződéses kötelezettségekként tekint rájuk. A DCFR esetében ez a szemlélet magától értetődik, hiszen, bár említi a kezelési szerződés a közfinanszírozású egészségügyi szolgáltatások tekintetében történő alkalmazásának lehetőségét, a tervezet a magánszférában, szolgáltatásként nyújtott kezelésekre koncentrál. A BGB esetében - bár felmerült egy közjogi alapokon nyugvó szabályozás lehetösége - a régóta egységes bírói gyakorlat megállapításaira tekintettel döntöttek a betegjogok szerződéses kötelezettségként történő rögzítése mellett.

A DCFR rendelkezései körében - az egészségügyi szolgáltató és a beteg kapcsolata szempontjából - a fent ismertetett és elemzett rendelkezéseken kívül komoly jelentőséggel bírnak az egészségügyi szolgáltató szervezetek kötelezettségei. E körben a tervezet azokat az eseteket szabályozza, amikor az egészségügyi szolgáltató önálló jogviszony alapján egy harmadik személyhez köthető egészségügyi intézményben kezeli a beteget. Ilyenkor az intézmény köteles tájékoztatni a beteget arról a körülményről, hogy nem ő a szerződő fél. Amennyiben pedig a beteg számára nem ismert - a szerződés szerinti - egészségügyi szolgáltató személye, az intézményt kell egészségügyi szolgáltatónak tekinteni, hacsak ésszerü időn belül nem tájékoztatja a beteget vele jogi kapcsolatban lévő egészségügyi szolgáltató személyéröl. ${ }^{57}$

A fenti rendelkezés szintén a beteg, mint gyengébb fél védelmét szolgálja, azonban - a hazai szabályozást, illetve gyakorlati tapasztalatokat figyelembe véve - nem kifejezetten fogyasztóvédelmi céllal. Társadalombiztosítási ellátásként nyújtott egészségügyi szolgáltatások esetében is gyakran előfordul ugyanis, hogy nem az intézményt fenntartó közszolgáltató, hanem egy vele önálló jogviszonyban álló másik egészségügyi szolgáltató nyújtja a kezelést. Ez viszont a

${ }^{57}$ DCFR IV. C. $-8: 111$ : Obligations of treatment-providingorganisations (1)-(2) 
beteg számára nem feltétlenül egyértelmü, ez pedig megnehezítheti a szerződésből eredő igények érvényesítését. A tervezet fent ismertetett rendelkezései ezért azt hivatottak kiküszöbölni, hogy e helyzetből adódóan hátrány érje a beteget.

Ez a megoldás a hazai szabályozás számára sem ismeretlen, az egészségügyi tevékenység végzésének egyes kérdéseiről szóló 2003. évi LXXXIV. törvény (Eütev.) 19/A. § értelmében ugyanis a beteg, illetve hozzátartozója az egészségügyi szolgáltatás során vagy az azzal összefüggésben keletkezett kára megtéritésére vonatkozó igényét közvetlenül a közszolgáltatást nyújtó egészségügyi szolgáltatóval szemben érvényesitheti, függetlenül attól, hogy az egészségügyi közszolgáltató milyen jogviszonyban foglalkoztatta a kárt okozó egészségügyi dolgozót. Az Eütev. fenti rendelkezése, ugyan nem ír elő tájékoztatási kötelezettséget az egészségügyi közszolgáltató, mint - a kezelésre irányuló jogviszony szempontjából - harmadik személy számára, az esetleges igényérvényesítés esetére lehetővé teszi, hogy a beteg bármelyik féllel szemben fellépjen.

A kezelési szerződés BGB-beli rögzítése kapcsán szó esett az egészségügyi szolgáltatások nyújtásával összefüggésben okozott károkkal kapcsolatos perekben kialakult bírói gyakorlatról, amely nem csupán a betegjogi természetü rendelkezésekre volt hatással. A BGB Bizonyitási teher a kezelési, illetve tájékoztatási hibákért való felelősség esetén címet viselő $§ 630 \mathrm{~h}$ szakasza vélelmeket állít fel, amelyek által megkönnyíti a kezelési hibákból eredő károkkal kapcsolatos jogviták rendezését.

\section{Összegző gondolatok}

A jogviszony leglényegesebb ismérveit tekintve a DCFR és a BGB szabályozása - első ránézésre - azonos irányt követ. A kezelési szerződést egyaránt gondossági kötelemnek tekintik, a teljesítés zsinórmértékét pedig mindkét koncepció a szolgáltatás sajátosságait szem elött tartva határozza meg. A beteg életét, testi épségét és egészségét, mint az emberi személyiség leglényegesebb elemeit érintő egészségügyi szolgáltatással összefüggésben őt megillető jogokat az egészségügyi szolgáltató oldalán megjelenő kötelezettségekként szabályozzák.

Összevetve a fentieket a hazai szabályozással, az a következtetés vonható le, hogy az elemzés tárgyát képező koncepciók annyiban térnek az egészségügyi szolgáltató és a beteg közötti jogviszony az Eütv. által meghatározott kereteihez képest, hogy expressis verbis rögzítik az egészségügyi szolgáltatásra irányuló jogviszony szerződéses voltát. A felek jogállása szempontjából ez nem bír jelentőséggel, hiszen az Eütv-benkatalogizált betegjogok ugyanúgy biztosítják a beteg autonómiáját és mellérendelt helyzetét, mint BGB-ben és a DCFR-ben rögzített - lényegüket tekintve azonos tartalmú - szerződéses kötelezettségek. 
Ugyanez mondható el a szolgáltatás nyújtása körében irányadó gondossági mércéről, illetve alkalmazandó szakmai és etikai normákról.

A kezelési szerződés BGB-beli rögzítése mögött húzódó megfontolásokra visszatekintve az állapítható meg, hogy a német jogrendszernek a polgári jogi kódex módosítását megelőzően komoly hiányossága volt a betegjogok szabályozásának hiánya. Az Eütv. ezzel szemben e vonatkozásban kielégítő szabályozást nyújt, így a jogbiztonsággal, illetve az alapvető jogok és az emberi személyiség védelmével aggályok nem jöhetnek szóba a magyar szabályozás esetében. A BGB egyetlen nóvuma az egészségügyi szolgáltató felelősségére vonatkozó szabályozás, amely azonban a tevékenység jellegéhez köthető, nem pedig a felek viszonyához.

A DCFR kapcsán fontos kiemelni, hogy a tagállami szerződési jogi szabályozások harmonizációjának egyik eszközeként elsősorban a magán-egészségügyi szolgáltatásokra lett szabva. Hazánkban azonban a lakosság többsége társadalombiztosítási ellátásként vesz igénybe egészségügyi szolgáltatásokat, melyek esetében a jogszabály keletkeztet ellátási kötelezettséget. A beteget a kezeléssel összefüggésben megillető jogok szerződéses kötelezettségként történő rögzítése még úgy is idegen a kezelés nyújtására irányuló jogviszonytól, hogy határozottan elismerjük a beteg egyenjogúságát, autonómiáját és mellérendeltségét.

Látni kell továbbá, hogy az egészségügyi ellátásokkal összefüggő - feltétel nélküli érvényesülést kívánó - betegjogok alkalmazási köre szélesebb a DCFR, illetve a BGB szerint a kezelési szerződésénél (lásd pl. sürgős szükség esetén nyújtott egészségügyi ellátás, közegészségügy, népegészségügy). Az emberi élet, testi épség és egészség védelmére, mint kiemelt társadalmi érdekre tekintettel az ágazatban irányadó, a társadalmi igényeknek megfelelő ellátás biztosítását célzó szakmai és egyéb követelmények érvényesülési körének meghatározásaezért nem eshet ki a közjogi szabályozás alól. Ha tehát a Ptk. vagy akár az Eütv. a DCFR-hez vagy a BGB-hez hasonló módon, akár a felek autonómiájának és mellérendeltségének deklarációja, akár a magán egészségügyi szolgáltatások megfelelő szabályozása érdekében önálló szerződéstípusként rögzítené a kezelési szerződést, az ágazati szabályozásra továbbra is szükség lenne a jelenlegi formájában.

\section{Felhasznált irodalom}

- Dominik Franzki: Der Behandlungsvertrag, EinneuerVertragstypusimBürgerichenGesetzbuch, Göttingen, Universitätsverlag Göttingen, 2014. 
- Dósa Ágnes: Az orvos kártérítési felelőssége, Budapest, HVG-ORAC, 2010.

- Günther Brenner: Arzt und Recht, Stuttgart-New York, Gustav Fischer Verlag, 1983,

- Jobbágyi Gábor: Orvosi jog, Budapest, Szent István Társulat, 2010.

- Jobbágyi Gábor: Orvosi kezelési szerződés - új szerződésfajta a BGB-ben, In: Tanulmányok a 65 éves Lenkovics Barnabás tiszteletére, Budapest Győr, Eötvös József Könyv-és Lapkiadó Bt. - Széchenyi István Egyetem Deák Ferenc Állam- és Jogtudományi Kara

- Kemenes István: Az orvos kártérítési felelősségének egyes kérdései, Bírósági Döntvények Tára 2008/1.

- MauritsBarendrecht, Chris Jansen, Marco Loos, Andrea Pinna, RuiCascao, Stephanie van Gulijk: Principles of European Private Law, Service contracts, München, Sellier European Law Publishers, 2007., 796.

- $\quad$ Papp Tekla: Atipikus szerződések, Lectum Kiadó, Szeged, 2009.

- Tarr György: Gondolatok az orvosi jogról és az orvosi jogviszonyról, Magyar jog, XCIX. évfolyam I. szám

- Törő Károly: Az orvosi polgári jogi jogviszony, Budapest, KJK, 1965.

- Török Éva: Az európai szerződési jog fejlődésének tendenciái, Debreceni Jogi Mühely, VIII. évf. 4. sz. http://www.debrecenijogimuhely.hu /archivum/ 4_2011/ az_europai_szerzodesi_jog_fejlodesenek_tendenciai (letöltés időpontja: 2016. november 28.)

\section{Feldolgozott jogszabályok és egyéb dokumentumok}

- A Legfelsőbb Bíróság Civilisztikai Kollégiumának emlékeztetője a civilisztikai kollégiumvezetők 2008. január 23-25. napján megtartott országos tanácskozásán megvitatott kérdésekről. http://ibolyatibor.atw.hu/civkoll.pdf (letöltés időpontja: 2014. október 9.)

- A Polgári Törvénykönyvről szóló 2013. évi V. törvény (Ptk.)

- Az egészségügyi tevékenység végzésének egyes kérdéseiről szóló 2003. évi LXXXIV. törvény (Eütev.)

- Az egészségügyről szóló 1997. évi CLIV. törvény (Eütv.)

- Az Európai Parlament és a Tanács 2006/123/EK irányelve a belső piaci szolgáltatásokról.

- BürgerlichesGesetzbuchin der Fassung der Bekanntmachungvom 2. Januar 2002 (BGBl. I S. 42, 2909; 2003 I S. 738)

- COM 2003/C 63/01 - Action Planon a More Coherent European Contract Law

- GesetzzurVerbesserung der Rechte von Patientinnen und Patientenvom 20. Februar 2013. (PRG) 
- (Muster-)Berufsordnungfür die inDeutschlandtätigenÄrztinnen und Ärzte MBO-Ä 1997.

- Principles, Definitions and ModelRules of European Private Law,

DraftCommonFrame of Reference (DCFR)

http://ec.europa.eu/justice/contract/files/european-private-law_en.pdf

(letöltés időpontja: 2017. január 8.)

Feldolgozott bírósági és alkotmánybírósági határozatok

- $\quad$ BGH, 17.12.1985 - VI ZR 178/84

- $\quad$ BVerfG, 25.07.1979 - BvR 878/74 (108)

- EH 2008.1867

- LB. Pfv. III.22 627/1999.

- Pécsi Ítélótábla Pf.II.20.115/2009.

- $\quad$ PKKB. 31. P. 89.625/1994.

Kiss János Márk ügyvédjelölt, doktorandusz

A szerző jogász, oklevelét a Debreceni Egyetem Állam- és Jogtudományi Karán szerezte 2015-ben. Jelenleg a Debreceni Egyetem Marton Géza Állam- és Jogtudományi Doktori Iskola II. évfolyamos, levelező tagozatos doktorandusza, emellett a Nyíregyházi Ügyvédi Kamara névjegyzékébe felvett ügyvédjelölt. Kutatási területe az egészségügyi szolgáltatások magánjogi aspektusaira terjed ki. 